\title{
COMBINING DIFFERENT MCDM METHODS WITH THE COPELAND METHOD: AN INVESTIGATION ON MOTORCYCLE SELECTION
}

\author{
Aşkın ÖZDAĞOĞLU1, Murat Kemal KELEŞ ${ }^{2}$, Anıl ALTINATA ${ }^{3}$, Alptekin \\ ULUTAŞ ${ }^{4^{*}}$ \\ ${ }^{1}$ Dokuz Eylül University, Business Faculty, Business Department, Tinaztepe Campus, Izmir, Turkey, \\ askin.ozdagoglu@deu.edu.tr \\ 2 Isparta University of Applied Sciences, Keciborlu Vocational School, Transportation Services \\ Department, Isparta, Turkey, muratkemalk@gmail.com \\ ${ }^{3}$ Dokuz Eylül University, Business Faculty, Business Department, Tinaztepe Campus, Izmir, Turkey, \\ aaltinata@gmail.com \\ ${ }^{4}$ Sivas Cumhuriyet University, Faculty of Economics and Administrative Sciences, International Trade \\ and Logistics, Sivas, Turkey, aulutas@cumhuriyet.edu.tr
}

\begin{abstract}
There are many different multi-criteria decision making methods in the literature. These methods, which enable criteria with different measurement units to be examined together, allow choosing between alternatives. However, different methods can produce different results depending on the data set. The aim of this study is to combine the results obtained by applying different methods to the data set with the Copeland method. To this end, a problem with real data was first addressed. Technical data of motorcycle alternatives that can be preferred for individual needs were collected in terms of different criteria. The weights of these criteria were found by the PIPRECIA method. Six different multi-criteria decision making methods were used to evaluate motorcycle alternatives. These methods are MOPA, MOOSRA, COPRAS, $S A W, W P M$ and ROV. The sequencing results obtained from these methods were combined with the Copeland method and the results were discussed.

Keywords: Multi Criteria Decision Making (MCDM), Copeland, Pivot Pairwise Relative Criteria Importance Assessment (PIPRECIA), Multi Objective Performance Analysis (MOPA), Multi Objective Optimization on The Basis of Simple Ratio Analysis (MOOSRA), Complex Proportional Assessment (COPRAS), Simple Additive Weighting (SAW), Weighted Product Method (WPM), Range of Value (ROV), Motorcycle Selection.
\end{abstract}

Original Scientific Paper

Received: 24.09.2021

Accepted: 07.10.2021

Available online 16.10.2021

\section{Introduction}

Technological developments and innovations have changed the lifestyle of people today, which in turn increased the competition between firms that produce for very big markets.

\footnotetext{
${ }^{*}$ Corresponding author
} 
Therefore, even tiny differences between end products which are better suited for customers' needs can create a competitive advantage for the competing firms. Motorcycle market is a market that reaches high selling numbers and high financial volume (Yontar and Aras, 2018). Especially, sport motorcycle take attention due to their higher prices and higher technologies (Bilgin, 2018).

Sport motorcycle market is considered as a niche market in which many firms compete and create new and improved products. Sometimes as a hobby and sometimes as an adventurous desire, sport motorcycle fans follow the developments in the market very closely. They do look at some of the criteria when comparing different models. These can include technical specifications of the models or more subjective elements such as design.

In this highly competitive market, firms offer such products that are very close to each other in terms of criteria customer desire and in terms of performance. Different motorcycles offered by competing firms with close features can create confusion for sport motorcycle buyers.

Suzuki, Honda, Kawasaki and Yamaha are considered important firms in this market. BMW is another established producer, however in this study, due to closeness between the origin of the firms and offering similar features, first four producers are considered. The models are chosen among alternatives with motor capacity under 1 litre. Technical specifications of the selected models are taken from the official Turkish website of their respective firms while the prices considered are dated to the time the study was conducted.

The criteria which affects buyer decisions are found out by conducting interviews with sports motorcycle fans. The weights of the determined criteria are calculated with the PIPRECIA method. The four different firms which sell to the Turkish market are evaluated individually with multi criteria decision making methods of MOPA, MOOSRA, COPRAS, SAW, WPM and ROV. The results of these different methods are combined with the Copeland method and the outcome is discussed.

\section{Literature Review}

There are studies conducted in different topics of motorcycles in literature. Some examples from these studies include:

Risdiyanto et al. (2020), investigated people's choices for transportation between motorcycles and moto-taxis in Indonesia. Akarpa and Diler (2020) has taken an artistic approach to motorcycle design. In this context, they studied the usability of style and art fashions in design process of "CBF 500" model. Rojniruttikul (2017), studied a supplier selection problem for a firm in Thailand which produces motorcycle parts. Şenkayas et al. (2010), used AHP method for selecting best logistic supplier for Mondial Motorcycle company. Wongnitipat and Gerdsri (2010), also used AHP method for a supplier selection problem in a motorcycle firm. Lucci et al. (2021), analyzed the protective effects of fixing helmets with respect to the choice of helmet and helmet type which are important for motorcycle users. Ardahan and Güleç (2020), investigated the factors which encourage people to use motorcycles. Yontar and Aras (2018), studied the use of motorcycles in city traffic and traffic safety in İzmir. Kurtipek and Akbulut (2021), investigated the role of horseriding teams in forming a motorcycle culture. Ertaş and Aktaş (2017), studied the personal characteristics of people who joined motorcycle groups with respect to social identity theory. Bilgin (2018), used VIKOR method to compare gasoline and electric motorcycles; gathered new data for a new motorcycle design by surveying motorcycle users.

In this study, from several Multi-Criteria Decision Making (MCDM) models; Pivot Pairwise Relative Criteria Importance Assessment (PIPRECIA), Multi Objective Performance Analysis (MOPA), Multi Objective Optimization on The Basis of Simple Ratio Analysis (MOOSRA), 
Combining Different MCDM Methods With the Copeland Method: An Investigation on Motorcycle Selection

Complex Proportional Assessment (COPRAS), Simple Additive Weighting (SAW), Weighted Product Method (WPM), Range of Value (ROV) are used. Studies using PIPRECIA, MOPA, MOOSRA, ROV were lacking in literature. Additionally, there wasn't any study which used MCDM methods for motorcycle choice in literature. The table below shows application examples from literature for MCDM methods used in this study:

Table 1. Literature Review

\begin{tabular}{|c|c|c|}
\hline Authors & Problem & Methods \\
\hline Chatterjee et al. (2011) & $\begin{array}{l}\text { Material selection for an } \\
\text { engineering application }\end{array}$ & COPRAS and EVAMIX \\
\hline $\begin{array}{l}\text { Savitha and Chandrasekar } \\
\text { (2011) }\end{array}$ & $\begin{array}{l}\text { Network selection in } \\
\text { Heterogeneous Wireless Networks }\end{array}$ & WPM and SAW \\
\hline Jha et al. (2013) & Supplier Selection & ROV \\
\hline Özdağoğlu (2013) & $\begin{array}{l}\text { Comparison of press machine } \\
\text { alternatives required for production } \\
\text { facilities }\end{array}$ & COPRAS \\
\hline Sarkar et al. (2015) & $\begin{array}{l}\text { Development of a decision support } \\
\text { mechanism for non-traditional } \\
\text { machine selection }\end{array}$ & MOORA and MOOSRA \\
\hline Dey et al. (2016) & Supply chain application & MOPA \\
\hline Çakır (2017) & $\begin{array}{l}\text { Finding the weights of } \mathrm{CNC} \\
\text { machine selection criteria for a gear } \\
\text { producing firm }\end{array}$ & SWARA and Copeland \\
\hline Özdağoğlu et al. (2017) & $\begin{array}{l}\text { Machine selection for a dairy } \\
\text { products factory }\end{array}$ & Entropy and SAW \\
\hline Balusa and Singam (2018) & $\begin{array}{l}\text { Selection of underground mining } \\
\text { method }\end{array}$ & WPM and PROMETHE \\
\hline Stanujkic et al. (2018) & $\begin{array}{l}\text { Evaluation of websites of hotels in } \\
\text { tourism sector }\end{array}$ & PIPRECIA, WS, PLP \\
\hline $\begin{array}{l}\text { Özdağoğlu and Keleş } \\
\text { (2019) }\end{array}$ & $\begin{array}{l}\text { Analysis of financial performance of } \\
\text { the four big football clubs that have } \\
\text { stocks on BIST }\end{array}$ & Grey Entropy and ROV \\
\hline $\begin{array}{l}\text { Özdağoğlu and Keleş } \\
\text { (2019) }\end{array}$ & $\begin{array}{l}\text { Supplier selection for a furniture } \\
\text { producer }\end{array}$ & DEMATEL and MOOSRA \\
\hline Şenyiğit and Ünal (2019) & $\begin{array}{l}\text { Selection of the best suited RFID } \\
\text { system for the warehouse of a carpet } \\
\text { factory }\end{array}$ & BWM and MOPA \\
\hline Jauković-Jocić et al. (2020) & $\begin{array}{l}\text { Determining the weights of the } \\
\text { criteria affecting the evaluation of e- } \\
\text { learning materials }\end{array}$ & $\begin{array}{l}\text { PIPRECIA-Interval- } \\
\text { Valued Triangular Fuzzy } \\
\text { ARAS }\end{array}$ \\
\hline Karakuş et al. (2020) & $\begin{array}{l}\text { Geographical information system } \\
\text { based sanitary storage site selection } \\
\text { in Sivas city in Turkey }\end{array}$ & AHP, SAW and CODAS \\
\hline Meshram et al. (2020) & $\begin{array}{l}\text { Evaluation and prioritization of } \\
\text { water basins }\end{array}$ & SAW and TOPSIS \\
\hline Yarlıkaş and Can (2020) & $\begin{array}{l}\text { Finding the weights of criteria that } \\
\text { affects green supply chain } \\
\text { management }\end{array}$ & SWARA and Copeland \\
\hline
\end{tabular}




\section{Methodology}

In this chapter, the procedures of the methods in the study are explained with the equations. Table 2 shows the procedure of PIPRECIA method.

$j:$ criterion; $j=1,2,3, \ldots, n$

$s_{j}$ : relative importance

$k_{j}$ : coefficient of criterion $j$

$q_{j}$ : weight of criterion $j$ before normalization

$w_{j}$ : normalized weight of criterion $j$

Table 2. PIPRECIA Process

\begin{tabular}{|c|c|}
\hline Steps & Equations \\
\hline $\begin{array}{l}\text { Evaluation of the } \\
\text { importance of the criterion } \\
\text { according to the criterion in } \\
\text { the following rank by the } \\
\text { decision maker }\end{array}$ & $s_{j}=\left\{\begin{array}{c}\text { criterion } j \text { is important than criterion }(j-1) \Longrightarrow s_{j}>1 \\
\text { importance of } j=\text { importance of }(j-1) \Longrightarrow s_{j}=1 \\
\text { criterion }(j-1) \text { is important than criterion } j \Rightarrow s_{j}<1\end{array}\right.$ \\
\hline $\begin{array}{l}\text { Calculation of the } \\
\text { coefficient according to the } \\
\text { expert's opinions }\end{array}$ & $k_{j}=\left\{\begin{array}{c}j=1 \Longrightarrow 1 \\
j>1 \Longrightarrow 2-s_{j}\end{array}\right.$ \\
\hline $\begin{array}{l}\text { Finding the weights of } \\
\text { criteria before } \\
\text { normalization }\end{array}$ & $q_{j}=\left\{\begin{array}{c}j=1 \Longrightarrow 1 \\
j>1 \Rightarrow \frac{q_{j-1}}{k_{j}}\end{array}\right.$ \\
\hline $\begin{array}{l}\text { Finding the weights of } \\
\text { criteria }\end{array}$ & $w_{j}=\frac{q_{j}}{\sum_{j=1}^{n} q_{j}}$ \\
\hline
\end{tabular}

Source: Stanujkic et al. (2017)

Table 3 shows the process of MOPA method.

$i$ : alternative $; i=1,2,3, \ldots, m$

$j:$ criterio $; j=1,2,3, \ldots, n$

$x_{i j}$ : performance value of alternative $i$ with respect to criterion $j$

$n_{i j}$ : normalized value

$M W P_{i j}$ : modified weighted performance

$j$ : benefit criterion; $j=1,2,3, \ldots, g$

$w_{j}$ : weight of criterion $j$

AMWP $P_{i}^{B}$ : aggregated value for benefit criteria

$j:$ cost criterion; $j=g+1, g+2, g+3, \ldots$,

$A M W P_{i}^{C}:$ aggregated value for cost criteria

$B C R_{i}$ : benefit cost ratio for alternative $i$ 
Combining Different MCDM Methods With the Copeland Method: An Investigation on Motorcycle Selection

Table 3. MOPA Process

\begin{tabular}{ll}
\hline \multicolumn{1}{c}{ Steps } & Equations \\
\hline Construction of the decision matrix & $D=\left[\begin{array}{cccc}x_{11} & x_{12} & \ldots & x_{1 n} \\
x_{21} & x_{22} & \ldots & x_{2 n} \\
\ldots & \ldots & \ldots & \ldots \\
x_{m 1} & x_{m 2} & \ldots & x_{m n}\end{array}\right]$ \\
Normalization & $n_{i j}=\frac{x_{i j}}{\sum_{i=1}^{m} x_{i j}}$ \\
Modified weighted normalized values & $M W P_{i j}=\frac{n_{i j}}{\left(1-w_{j}\right)^{w_{j}}}$ \\
$\begin{array}{l}\text { Total aggregated modified weighted values } \\
\text { for benefit criteria }\end{array}$ & $A M W P_{i}^{B}=\sum_{j=1}^{g} M W P_{i j}$ \\
$\begin{array}{l}\text { Total aggregated modified weighted values } \\
\text { for cost criteria }\end{array}$ & $A M W P_{i}^{C}=\sum_{j=g+1}^{n} M W P_{i j}$ \\
Benefit cost ratio for each alternative & $B C R_{i}=\frac{A M W P_{i}^{B}}{A M W P_{i}^{C}}$ \\
\hline
\end{tabular}

Source: Dey et al. (2016)

The last step in Table 3 shows the values of the alternatives in the problem. The highest value shows the best alternative. Table 4 shows the process of MOOSRA method.

$j:$ benefit criterion; $j=1,2,3, \ldots, g$

$j:$ cost criterion; $j=g+1, g+2, g+3, \ldots, n$

$r_{i j}$ : normalized performance value

$v_{i j}$ : weighted normalized performance value

$y_{i}$ : performance value of alternative $i$

Table 4. MOOSRA Process

\begin{tabular}{lc}
\hline \multicolumn{1}{c}{ Steps } & Equations \\
\hline Construction of decision matrix & $D=\left[\begin{array}{cccc}x_{11} & x_{12} & \ldots & x_{1 n} \\
x_{21} & x_{22} & \ldots & x_{2 n} \\
\ldots & \ldots & \ldots & \ldots \\
x_{m 1} & x_{m 2} & \ldots & x_{m n}\end{array}\right]$ \\
Normalized values & $r_{i j}=\frac{x_{i j}}{\sqrt{\sum_{i=1}^{m} x_{i j}^{2}}}$ \\
Weighted normalized values & $v_{i j}=w_{j} * r_{i j}$ \\
$\begin{array}{l}\text { Calculation of the performance values of } \\
\text { the alternatives }\end{array}$ & $y_{i}=\frac{\sum_{j=1}^{g} v_{i j}}{\sum_{j=g+1}^{n} v_{i j}}$ \\
\hline
\end{tabular}

Source: Adalı \& Işık (2017)

Table 5 shows the process of COPRAS method.

$j$ : benefit criterion; $j=1,2,3, \ldots, g$

$j:$ cost criterion; $j=g+1, g+2, g+3, \ldots, n$

$x_{i j}^{*}$ : normalized value

$d_{i j}$ : weighted normalized value 
$S_{i+}$ : sum of weighted normalized value for benefit criteria

$S_{i-}$ : sum of weighted normalized value for cost criteria

$Q_{i}$ : relative importance value of alternative $i$

$P_{i}:$ performance value of alternative $i$

Table 5. COPRAS Process

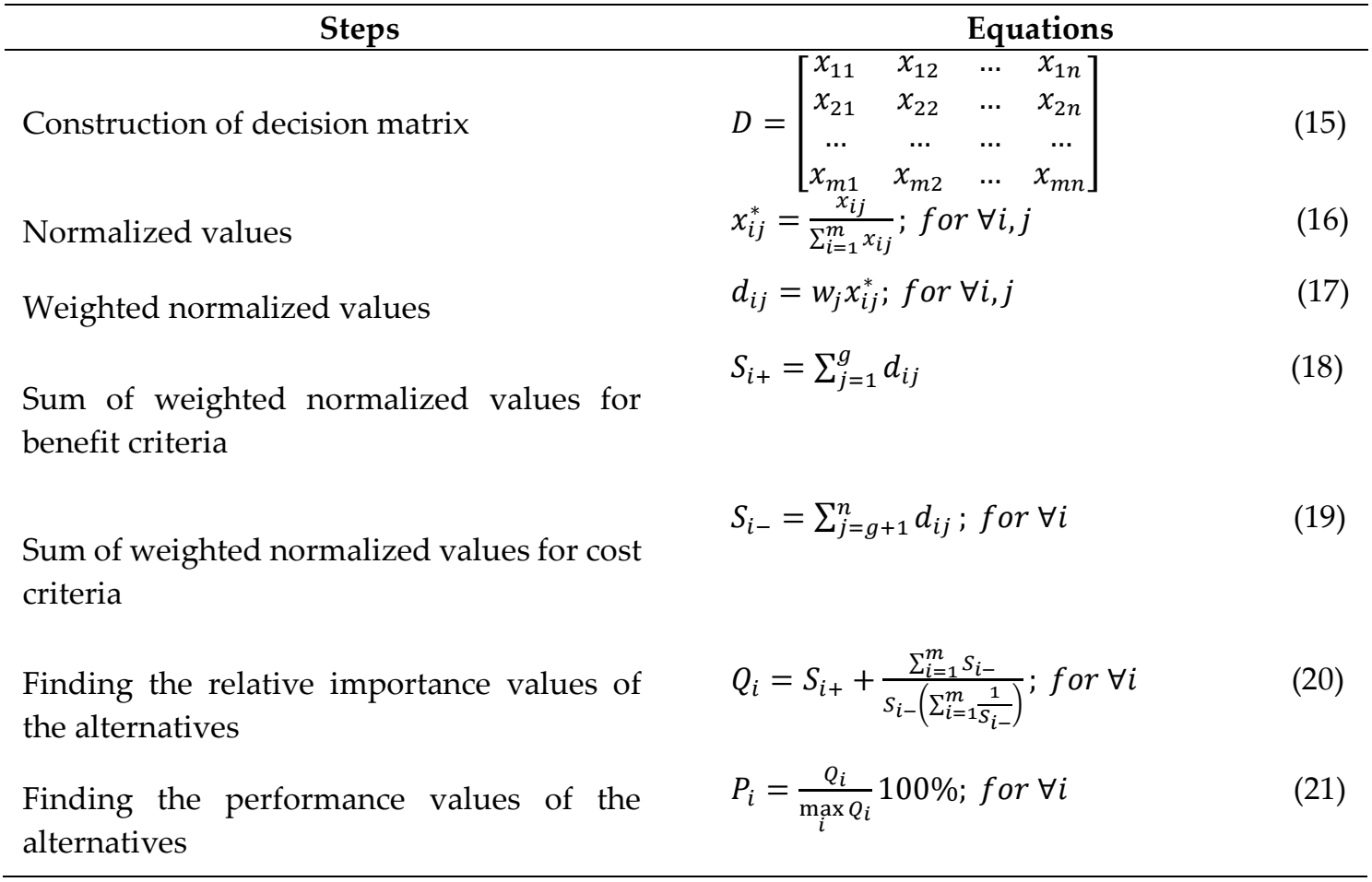

Source: Chatterjee et al. (2011)

Table 6 shows the procedure of SAW method.

$n_{i j}$ : normalized value of alternative $i$ with respect to criterion $j$

$S A W_{i}$ : performance value of alternative $i$ according to $S A W$ method

Table 6. SAW Process

\begin{tabular}{ll}
\hline \multicolumn{1}{c}{ Steps } & \multicolumn{3}{c}{ Equations } \\
\hline Construction of decision matrix & $D=\left[\begin{array}{cccc}x_{11} & x_{12} & \ldots & x_{1 n} \\
x_{21} & x_{22} & \ldots & x_{2 n} \\
\ldots & \ldots & \ldots & \ldots \\
x_{m 1} & x_{m 2} & \ldots & x_{m n}\end{array}\right]$ \\
Normalization for benefit criteria & $n_{i j}=\frac{x_{i j}}{\max _{j} x_{i j}}$ \\
Normalization for cost criteria & $n_{i j}=\frac{\min _{j} x_{i j}}{x_{i j}}$ \\
$\begin{array}{l}\text { Finding the performance values of } \\
\text { the alternatives }\end{array}$ & $S A W_{i}=\sum_{j=1}^{n} w_{j} n_{i j}$
\end{tabular}

Source: Ömürbek et al. (2016).

Table 7 shows the procedure of WPM method.

$n_{i j}$ : normalized value of alternative $i$ with respect to criterion $j$

$W P M_{i}$ : performance value of alternative $i$ according to WPM method 
Combining Different MCDM Methods With the Copeland Method: An Investigation on Motorcycle Selection

Table 7. WPM Process

\begin{tabular}{ll}
\hline \multicolumn{1}{c}{ Steps } & \multicolumn{3}{c}{ Equations } \\
\hline Construction of decision matrix & $D=\left[\begin{array}{cccc}x_{11} & x_{12} & \ldots & x_{1 n} \\
x_{21} & x_{22} & \ldots & x_{2 n} \\
\ldots & \ldots & \ldots & \ldots \\
x_{m_{1} 1} & x_{m 2} & \ldots & x_{m n}\end{array}\right]$ \\
Normalization for benefit criteria & $n_{i j}=\frac{x_{i j}}{\max _{j} x_{i j}}$ \\
Normalization for cost criteria & $n_{i j}=\frac{\min _{j} x_{i j}}{x_{i j}}$ \\
$\begin{array}{l}\text { Finding the performance values of } \\
\text { the alternatives }\end{array}$ & $W P M_{i}=\prod_{j=1}^{n} n_{i j}{ }^{w_{j}} ; \forall i i c ̧ i n$
\end{tabular}

Source: Nezhad et al. (2015); Taka et al. (2017)

Table 8 shows the procedure of ROV method.

$j:$ benefit criterion; $j=1,2,3, \ldots, g$

$j:$ cost criterion; $j=g+1, g+2, g+3, \ldots, n$

$u_{i}^{+}$: the best utility value of alternative $i$

$u_{i}^{-}$: the worst utility value of alternative $i$

$u_{i}$ : midpoint of alternative $i$

Table 8. ROV Process

\begin{tabular}{ll}
\hline \multicolumn{1}{c}{ Steps } & \multicolumn{3}{c}{ Equations } \\
\hline Construction of decision matrix & $D=\left[\begin{array}{cccc}x_{11} & x_{12} & \ldots & x_{1 n} \\
x_{21} & x_{22} & \ldots & x_{2 n} \\
\ldots & \ldots & \ldots & \ldots \\
x_{m 1} & x_{m 2} & \ldots & x_{m n}\end{array}\right]$ \\
Normalization (Benefit criterion) & $\bar{x}_{i j}=\frac{x_{i j}-\min _{i=1}^{m}\left(x_{i j}\right)}{\max _{i=1}^{m}\left(x_{i j}\right)-m n_{i=1}^{m}\left(x_{i j}\right)}$ \\
Normalization (Cost criterion) & $\bar{x}_{i j}=\frac{\max _{i=1}^{m}\left(x_{i j}\right)-x_{i j}}{\max _{i=1}^{m}\left(x_{i j}\right)-\min _{i=1}^{m}\left(x_{i j}\right)}$ \\
Finding of the best utility values & $u_{i}^{+}=\sum_{j=1}^{g} \bar{x}_{i j} w_{j}$ \\
Finding of the worst utility values & $u_{i}^{-}=\sum_{j=g+1}^{n} \bar{x}_{i j} w_{j}$ \\
Finding of the midpoints & $u_{i}=\frac{u_{i}^{+}+u_{i}^{-}}{2}$
\end{tabular}

Source: Madić et al. (2016)

The highest midpoint shows the best alternative according to ROV method.

Table 9 shows the procedure of Copeland method.

$m$ : the total number of MCDM method

$k$ : rank value according to MCDM method

$n$ : total number of alternativestoplam alternatif sayıs

$i$ : rank value of alternative in the row

$j$ : rank value of alternative in the column

$r_{k}\left(A_{i}\right)$ :rank value of alternative $i$ according to method $k$ 
$f_{k}(i, j)$ : superiority of alternative $i$ over alternative $j$

$S(i, j)$ : overall superiority of alternative $i$ to alternative $j$

$G(i, j)$ : win, loss and tie conditions of alternative $i$ over alternative $j$

$G P_{i}$ : win score alternative $i$

$Y P_{i}$ : loss score for alternative $i$

$C P_{i}$ : Copeland score of alternative $i$

Table 9. Copeland Process

\begin{tabular}{cc}
\hline Steps & Equations \\
\hline Comparative superiorities & $f_{k}(i, j)=\left\{\begin{array}{l}r_{k}\left(A_{i}\right)<r_{k}\left(A_{j}\right) \wedge i \neq j \Rightarrow 1 \\
r_{k}\left(A_{i}\right)>r_{k}\left(A_{j}\right) \wedge i \neq j \Rightarrow 0 \\
r_{k}\left(A_{i}\right)=r_{k}\left(A_{j}\right) \vee i \neq j \Rightarrow 0\end{array}\right.$ \\
$S(i, j)=\sum_{k=1}^{m} f_{k}(i, j)$
\end{tabular}

Total comparative superiorities

Win, loss and tie conditions

$$
\begin{gathered}
G(i, j)=\left\{\begin{array}{c}
S(i, j)>S(j, i) \wedge i \neq j \Rightarrow 1 \\
S(i, j)=S(j, i) \wedge i \neq j \Rightarrow \frac{1}{2} \\
S(i, j)<S(j, i) \wedge i \neq j \Rightarrow-1
\end{array}\right. \\
G P_{i}=\text { in case of } \sum_{i=1}^{n} G(i, j), G(i, j)>0
\end{gathered}
$$

Winning score

$$
Y P_{i}=\text { in case of } \sum_{i=1}^{n} G(i, j), G(i, j)<0
$$

Loss score

$$
C P_{i}=G P_{i}+Y P_{i}
$$

Copeland score

Source: Çakır (2017)

\section{Application}

In order to integrate the results obtained from different MCDM methods, firstly, a problem in which the real values can be found was tried to be determined. For this purpose, the problem of choosing a motorcycle for motorcycle enthusiasts is discussed. Within the scope of the study, four sports motorcycle alternatives belonging to Far East brands sold in Turkey were evaluated:

The alternatives are as follows.

Alternative 1: Suzuki GSX- R 1000 R ABS

Alternative 2: Honda CBR 1000 RR- R Fireblade SP

Alternative 3: Yamaha YZF $1000 \mathrm{R}$

Alternative 4: Kawasaki Ninja ZX-10R

In the first stage of the application part, the criteria to be considered in the selection of motorcycles were determined as a result of interviews with motorcycle enthusiasts. Criteria explanations can be seen in Table 10. 
Combining Different MCDM Methods With the Copeland Method: An Investigation on Motorcycle Selection

Table 10. Criteria Information

\begin{tabular}{llll}
\hline Criteria code & \multicolumn{1}{c}{ Criteria name } & \multicolumn{1}{c}{ Measurement units } & Types \\
\hline K1 & Engine performance & Kilowatt & Benefit \\
K2 & Weight of motorcycle & Kilogram & Cost \\
K3 & Fuel consumption & Litre/100 kilometres & Cost \\
K4 & Price of motorcycle & Turkish Liras & Cost \\
K5 & Design & Grade & Benefit \\
K6 & Fuel depot size & Litre & Benefit \\
\hline
\end{tabular}

The meanings of the evaluation criteria given in Table 9 are explained as follows:

The criterion coded $\mathrm{K} 1$ is called "Engine performance". The measurement of engine performance, which directly affects adrenaline-generating events such as 0-100 and 0-200 acceleration, top speed, desired by sports motorcycle enthusiasts, was evaluated in kilowatt in this study. The numerical magnitude of the engine power value will have a positive effect on take-off acceleration, intermediate accelerations and top speed achievable.

The "Weight of the motorcycle" criterion is the K2 coded criterion. The weight criterion has a huge impact on acceleration, such as engine performance. Motorcycles with the same power will always accelerate in less time with less weight. In addition, the increase in weight will negatively affect fuel consumption. The low weight also has a positive effect on handling. Finally, outside of driving; we can say that light motorcycles create a better user experience when parking and in subtle manoeuvres.

The K3 coded criterion is the "Fuel consumption" criterion. In the study, the average fuel value consumed in 100 kilometres given by the manufacturers was used. Users expect low fuel consumption; It can be said that among the engines that produce the same power, the one with less fuel consumption is more efficient, which is a situation that motorcycle enthusiasts can enjoy.

The K4 coded criterion is the "Price" criterion. We can think that using a sports motorcycle, which is an expensive hobby, is considered by many motorcycle enthusiasts as price / performance. The same is true for automobiles. Considering that many evaluation magazines set an $\mathrm{F} / \mathrm{P}$ criterion while scoring new models, we can say that the same is true for motorcycle enthusiasts. Therefore, potential customers are more interested in low-priced products.

The K5 coded criterion is "Design". This criterion is a more subjective criterion. In this study, the design criteria were found with their average values as a result of the interviews with the enthusiasts. The design of sports motorcycles, which can be considered a luxury hobby, is very important for sports enthusiasts. Harder and fiercer designs, bright colours and rim design affect the emotional reactions of the users and change the perception of quality.

The criterion coded K6 is "Fuel depot size". Considering that sports motorcycles burn a little more, they want the tank size to be sufficient for users to avoid the trouble of intercity trips and the trouble of constantly visiting the gas station.

The PIPRECIA method was used to investigate the effect of the criteria on the problem. After applying the PIPRECIA method steps, the results are given in Table 11. 
Table 11. PIPRECIA Calculations

\begin{tabular}{lcccc}
\hline \multicolumn{1}{c}{ Criteria } & $\boldsymbol{s}_{\boldsymbol{j}}$ & $\boldsymbol{k}_{\boldsymbol{j}}$ & $\boldsymbol{q}_{\boldsymbol{j}}$ & $\boldsymbol{w}_{\boldsymbol{j}}$ \\
\hline Engine performance (K1) & & 1,0000 & 1,0000 & 0,2076 \\
Weight of motorcycle (K2) & 0,9500 & 1,0500 & 0,9524 & 0,1977 \\
Fuel consumption (K3) & 0,9000 & 1,1000 & 0,8658 & 0,1798 \\
Price of motorcycle (K4) & 0,9000 & 1,1000 & 0,7871 & 0,1634 \\
Design (K5) & 0,8500 & 1,1500 & 0,6844 & 0,1421 \\
Fuel depot size (K6) & 0,7000 & 1,3000 & 0,5265 & 0,1093 \\
\hline
\end{tabular}

We can guess that the first thing that sports bikers consider is pleasure. The most important thing that affects the perception of pleasure in enthusiasts is acceleration and the feeling of acceleration. The two criteria that most affect acceleration, the K1 (motor performance) criterion with a score of 0,2076 and the K2 (weight) criterion with a score of 0,1977, had the highest weight in the overall evaluation result.

The weight values of fuel consumption, price and design are relatively close to each other. It can be said that each of these is included as a separate evaluation criterion under the expectation of acceleration and pleasure.

The fuel depot size criterion took in the last place with a score of 0,1093. The fact that this criterion, which has a more practical meaning when considering the desire of motorcycle enthusiasts, is in the last place shows that sports motorcycle enthusiasts put such criteria in the last place.

After the criterion weights were found, the initial decision matrix of the motorcycle alternatives was created. The decision matrix forming the initial step for all MCDM methods is given in Table 12.

Table 12. Decision Matrix

\begin{tabular}{lllllll}
\hline Alternatives & K1 & K2 & K3 & K4 & K5 & K6 \\
\hline Suzuki & & & & & & \\
Honda & 148,5 & 203 & 7,57 & 265.000 & 8,5 & 16,0 \\
Yamaha & 160,0 & 201 & 6,25 & 326.000 & 7,0 & 16,1 \\
Kawasaki & 147,1 & 201 & 7,20 & 241.000 & 6,5 & 17,0 \\
\hline \multicolumn{5}{l}{ Reference: Suzuki (2021); Honda, (2021); Yamaha (2021); Kawasaki (2021) }
\end{tabular}

In order to evaluate these alternatives, whose measurement units are very different from each other, calculations were made with MOPA, MOOSRA, COPRAS, SAW, WPM and ROV methods.

The values and rankings according to the MOPA, MOOSRA and COPRAS methods are shown in Table 13. 
Combining Different MCDM Methods With the Copeland Method: An Investigation on Motorcycle Selection

Table 13. MOPA, MOOSRA and COPRAS Values and Rankings

\begin{tabular}{lllllllr}
\hline & $\begin{array}{l}\text { MOPA } \\
\text { Value }\end{array}$ & $\begin{array}{l}\text { MOPA } \\
\text { Rank }\end{array}$ & $\begin{array}{l}\text { MOOSRA } \\
\text { Value }\end{array}$ & $\begin{array}{l}\text { MOOSRA } \\
\text { Rank }\end{array}$ & $\begin{array}{l}\text { COPRAS } \\
\text { Value }\end{array}$ & \multicolumn{2}{l}{$\begin{array}{l}\text { COPRAS } \\
\text { Rank }\end{array}$} \\
\hline Suzuki & 1,0148 & 1 & 0,8717 & 1 & 100,000 & 1 \\
Honda & 0,9724 & 4 & 0,8515 & 2 & 98,9137 & 3 \\
Yamaha & 0,9937 & 2 & 0,8512 & 3 & 99,3781 & 2 \\
Kawasaki & 0,9858 & 3 & 0,8356 & 4 & 97,8374 & 4 \\
\hline
\end{tabular}

The values and rankings according to the SAW, WPM and ROV methods are shown in Table 14.

Table 14. SAW, WPM and ROV Values and Rankings

\begin{tabular}{ccrrrrr} 
Results & $\begin{array}{c}\text { SAW } \\
\text { Value }\end{array}$ & $\begin{array}{c}\text { SAW } \\
\text { Rank }\end{array}$ & $\begin{array}{c}\text { WPM } \\
\text { Value }\end{array}$ & $\begin{array}{c}\text { WPM } \\
\text { Rank }\end{array}$ & $\begin{array}{c}\text { ROV } \\
\text { Value }\end{array}$ & $\begin{array}{c}\text { ROV } \\
\text { Rank }\end{array}$ \\
\hline Alternatives & & 1 & 0.9191 & 1 & 0.2441 & 4 \\
Honda & 0.9165 & 3 & 0.9109 & 3 & 0.2970 & 1 \\
Yamaha & 0.9174 & 2 & 0.9127 & 2 & 0.2633 & 2 \\
Kawasaki & 0.9071 & 4 & 0.9028 & 4 & 0.2507 & 3 \\
\hline
\end{tabular}

After the calculations were made according to six different methods, Copeland processes were started in order to combine the obtained rankings. Comparative overall superiorities between alternatives are shown in Table 15 .

Table 15. Superiorities

\begin{tabular}{crrrr}
\hline$S(i, j)$ & Suzuki & Honda & Yamaha & Kawasaki \\
\hline Suzuki & 0 & 5 & 5 & 5 \\
Honda & 1 & 0 & 2 & 5 \\
Yamaha & 1 & 4 & 0 & 6 \\
Kawasaki & 1 & 1 & 0 & 0 \\
\hline
\end{tabular}

Win, loss and tie conditions are in Table 16.

Table 16. Win, Loss and Tie Conditions

\begin{tabular}{crrrr}
\hline$G(i, j)$ & Suzuki & Honda & Yamaha & Kawasaki \\
\hline Suzuki & 0 & 1 & 1 & 1 \\
Honda & -1 & 0 & -1 & 1 \\
Yamaha & -1 & 1 & 0 & 1 \\
Kawasaki & -1 & -1 & -1 & 0 \\
\hline
\end{tabular}

Win, loss and Copeland scores of the alternatives are in Table 17. 
Table 17. Win, Loss and Copeland Scores

\begin{tabular}{crrrr}
\hline$G(i, j)$ & $G P_{i}$ & $Y P_{i}$ & $C P_{i}$ & Ranking \\
\hline Suzuki & 3 & 0 & 3 & 1 \\
Honda & 1 & -2 & -1 & 3 \\
Yamaha & 2 & -1 & 1 & 2 \\
Kawasaki & 0 & -3 & -3 & 4 \\
\hline
\end{tabular}

Looking at Table 12, Suzuki's model came to the fore as the best alternative in the ranking seen in Table 17, although it was ranked 2nd according to the "engine performance" criterion and 3rd according to the "weight" criterion. Suzuki, which is close to the models in the first row according to the counterweight criterion, has a much cheaper price tag than the Honda with the best engine performance. Suzuki also came to the fore in the "design" criterion and became the most admired model with 8,5 points. The differences in these areas overshadowed the low scores in fuel consumption and tank size, and the overall assessment was placed in the first place.

Kawasaki's model took the last place in this evaluation. Although it offers the best data on fuel consumption, the worst engine power and weight values influencing acceleration among these four and the second highest price tag could not save Kawasaki from being the last alternative.

\section{Conclusion}

Motorcycle selection can lead to indecision for sport motorcycle fans. Very similar offerings by competing firms and analysis of all technical details can be considered as causes for this hard decision problem. However, being a niche market and users being mostly hobbyist or adventurous people will push some criteria forward as being more important for these users. These are motor performance and weights of the motorcycles, which affects the most pleasure and feel of driving and acceleration. These two leave other criteria behind, such as fuel tank size which is more of a practical issue. Also, all alternatives in this study have very similar sizes of fuel tank and weights. It would be critical for firms trying to have an edge, to improve themselves in the areas of motor power while keeping a close eye on fuel consumption and to create a stylish aesthetic design. The prices will always be important in customer decisions as well.

In this study, results from different MCDM methods applied to a motorcycle selection problem dataset are combined with the Copeland method. In future studies, MCDM methods which are used in this study or other methods can be used on another problem and dataset, which then can be combined with the Copeland method for further analysis. This study will be helpful to sport motorcycle fans and producers in the market and may offer new insights.

\section{References}

Adalı, E. A., \& Işık, A. T. (2017). The multi-objective decision-making methods based on MULTIMOORA and MOOSRA for the laptop selection problem. Journal of Industrial Engineering International, 13. 229-237. DOI 10.1007/s40092-016-0175-5.

Akarpa, A., \& Diler, H. (2020). Sanat stil ilişkisi üzerine motosiklet tasarımı üzerinde bir araştırma. Mediterranean Journal of Humanities, 10(1), 1-10. DOI: 10.13114/MJH.2020.513.

Ardahan, F., \& Güleç, S. (2020). Bireyleri motosiklet kullanmaya motive eden faktörlerin çeşitli değişkenlere göre karşılaştırılması. Elektronik Sosyal Bilimler Dergisi, 19(73), 237-253. 
Combining Different MCDM Methods With the Copeland Method: An Investigation on Motorcycle Selection

Balusa, B. C., \& Singam, J. (2018). Underground mining method selection using WPM and PROMETHEE. Journal of the Institution of Engineers (India): Series D, 99(1), 165-171. https://doi.org/10.1007/s40033-017-0137-0.

Bilgin, H.Y. (2018). Yakıt Türüne Göre Motosiklet Seçimi ve Yeni Bir Tasarım. Başkent Üniversitesi Fen Bilimleri Enstitüsü, Yayımlanmamış Yüksek Lisans Tezi.

Çakır, E. (2017). Kriter Ağırlıklarının SWARA - Copeland Yöntemi ile Belirlenmesi: Bir Üretim İşletmesinde Uygulama. Adnan Menderes Üniversitesi Sosyal Bilimler Enstitüsü Dergisi, Cilt 4, Sayı 1, (42-56).

Chatterjee, P., Athawale, V. M., \& Chakraborty, S. (2011). Materials selection using complex proportional assessment and evaluation of mixed data methods. Materials and Design, 32, 851-860.

Dey, B., Bairag, B., Sarkar, B., \& Sanyal, S.K. (2016). Multi objective performance analysis: A novel multi-criteria decision making approach for a supply chain, Computers $\mathcal{E}$ Industrial Engineering, 94, 105-124. Doi: 10.1016/j.cie.2016.01.019.

Ertaş, M., \& Aktaş, G. (2017). Sosyal kimlik kuramı: motosiklet kullanıcılarının ïncelenmesi. 4. Disiplinlerarası Turizm Araştırmaları Kongresi, 9 - 12 Kasım 2017, Kuşadası, Aydın. 240247.

Honda, (2021). Teknik Özellikler. https://honda.com.tr/motosiklet/modeller/supersport/cbr1000rrr-fireblade-sp (21.01.2021).

Jauković-Jocić, K., Karabašević, D., \& Jocić, G. (2020). The use of the PIPRECIA method for assessing the quality of e-learning materials. Ekonomika, 66(3), 37-45. doi: 10.5937/ekonomika2003037J.

Jha, G. K., Chatterjee, P., Chatterjee, R., \& Chakraborty, S. (2013). Suppliers Selection in Manufacturing Environment using Range of Value Method. i-Manager's Journal on Mechanical Engineering, 3(3), 15-22.

Karakuş, C. B., Demiroğlu, D., Çoban, A., \& Ulutaş, A. (2020). Evaluation of GIS-based multicriteria decision-making methods for sanitary landfill site selection: the case of Sivas city, Turkey. Journal of Material Cycles and Waste Management, 22(1), 254-272. https://doi.org/10.1007/s10163-019-00935-0.

Kawasaki, (2021). Teknik Detaylar. http://www.kawasaki.com.tr/motosiklet/NinjaZx-10R/ZX10Rteknik.html (21.01.2021).

Kurtipek, A., \& Akbulut, D. (2021). At binicilik takımlarının motosiklet kültürü üzerindeki yansımaları. Kültür Araştırmaları Dergisi, (8), 155-174. DOI: 10.46250/kulturder.857828.

Lucci, C., Piantini, S., Savino, G., \& Pierini, M. (2021). Motorcycle helmet selection and usage for improved safety: a systematic review on the protective effects of helmet type and fastening. Traffic injury prevention, 1-11. https://doi.org/10.1080/15389588.2021.1894640.

Madić, M., Radovanović, M. \& Miodrag. M. (2016). Application of the ROV method for the selection of cutting fluids. Decision Science Letters, 5 (2), 245-254. doi: 10.5267/j.dsl.2015.12.001.

Meshram, S. G., Alvandi, E., Meshram, C., Kahya, E., \& Al-Quraishi, A. M. F. (2020). Application of SAW and TOPSIS in prioritizing watersheds. Water Resources Management, 34(2), 715732. https://doi.org/10.1007/s11269-019-02470-x. 
Nezhad, M.R.G., Zolfani, S.H., Moztarzadeh, F., Zavadskas, E.K. \& Bahrami, M. (2015). Planning the priority of high tech industries based on SWARA-WASPAS methodology: The case of the nanotechnology industry in Iran. Economic Research-Ekonomska Istraživanja, 28(1), 1111-1137. DOI: 10.1080/1331677X.2015.1102404.

Ömürbek, N., Karaatll, M., \& Balcl, H.F. (2016). Entropi Temelli MAUT ve SAW Yöntemleri İle Otomotiv Firmalarının Performans Değerlemesi. Dokuz Eylül Üniversitesi İktisadi ve İdari Bilimler Fakültesi Dergisi, 31(1), 227-255.

Özdağoğlu, A. (2013). İmalat işletmeleri için eksantrik pres alternatiflerinin COPRAS yöntemi ile karşılaştırılması. Gümüşhane Üniversitesi Sosyal Bilimler Enstitüsü Elektronik Dergisi, 4(8), $1-22$.

Özdağoğlu, A., \& Keleş, M.K. (2019). DEMATEL ve MOOSRA Bütünleşik Yaklaşımıyla Tedarikçi Seçimi: Mobilya Fabrikasında Bir Uygulama. II. Uluslararası İşletme ve Organizasyon Kongresi, 4-5-6 Eylül 2019, İzmir, 1641-1656.

Özdağoğlu, A., \& Keleş, M.K. (2019). Spor Yönetimi açısından Gri Entropi Tabanlı Rov Yöntemi İle 4 büyük futbol kulübünün finansal performans analizi. Süleyman Demirel Üniversitesi Sosyal Bilimler Enstitüsü Dergisi, (35), 107-123.

Özdağoğlu, A., Yakut, E., \& Bahar, S. (2017). Machine selection in a dairy product company with entropy and SAW methods integration. Dokuz Eylül Üniversitesi İktisadi İdari Bilimler Fakültesi Dergisi, 32(1), 341-359.

Risdiyanto, Munawar, A., Irawan, M. Z., \& Nugraha, A. A. (2020). Model selection of online motorcycle taxi and motorcycle modes on work trips. In IOP Conference Series: Materials Science and Engineering (Vol. 1007). 3rd Tarumanagara International Conference of the Applications of Technology and Engineering (TICATE) 2020 3-4 August 2020, Jakarta, Indonesia, IOP Publishing. doi:10.1088/1757-899X/1007/1/012059.

Rojniruttikul, N. (2017). A multi-criteria approach for supplier selection: Case of motorcycle parts manufacturer in Thailand. Review of Integrative Business and Economics Research, 6(3), 188193.

Sarkar, A., Panja, S. C., Das, D., \& Sarkar, B. (2015). Developing an Efficient Decision Support System for Non-Traditional Machine Selection: An Application of MOORA and MOOSRA. Production \& Manufacturing Research, 3(1), 324-342. DOI.org/10.1080/21693277.2014.895688.

Savitha, K., \& Chandrasekar, C. (2011). Vertical Handover decision schemes using SAW and WPM for Network selection in Heterogeneous Wireless Networks. Global Journal of Computer Science and Technology, 11(9), 19-24.

Şenkayas H., Öztürk M., \& Sezen G. (2010). Lojistik tedarikçilerin seçiminde analitik hiyerarşi süreci (ahp) yöntemi: mondial şirketinde bir uygulama. Pamukkale Universitesi Sosyal Bilimler Enstitusü Dergisi, (5), 161-175.

Şenyiğit, E., \& Ünal, Z. (2019). BWM-MOPA Yöntemi ile en iyi RFID sisteminin belirlenmesi. Avrupa Bilim ve Teknoloji Dergisi Özel Sayı, 9-14.

Stanujkic, D., Karabasevic, D., \& Sava, C. (2018). An application of the PIPRECIA and WS PLP methods for evaluating website quality in hotel industry. Quaestus, 12, 190-198.

Stanujkic, D., Zavadskas, E.K., Karabasevic, D., Smarandache, F., \& Turskis, Z. (2017). The Use of The Pivot Pairwise Relative Criteria Importance Assessment Method for Determining The Weights of Criteria. Romanian Journal of Economic Forecasting, 20(4), 116-133. 
Combining Different MCDM Methods With the Copeland Method: An Investigation on Motorcycle Selection

Suzuki, (2021). Teknik Özellikler. https://www.suzuki.com.tr/tr/motosiklet/gsxs-1000.html (21.01.2021).

Taka, M., Raygor, S. P., Purohit, R., \& Parashar, V. (2017). Selection of tool and work piece combination using Multiple Attribute Decision Making Methods for Computer Numerical Control turning operation. Materials Today: Proceedings 4. 5th International Conference of Materials Processing and Characterization (ICMPC 2016), 1199-1208.

Wongnitipat, S. \& Gerdsri, N. (2010). Supplier Evaluation and Selection: A Case Example of Motoraycle Manufacturing Company. KMUTT Research and Development Journal, 34 (1), 59-75.

Yamaha, (2021). Teknik Özellikler. https://www.yamahamotor.eu/tr/tr/products/motorcycles/supersport/yzf-r1/techspecs/ ( 21.01.2021)

Yarlıkaş, S., \& Can, Z. V. (2020). Yeşil tedarik zinciri yönetimini etkileyen faktörlerin önem sıralamalarının SWARA ve Copeland yöntemleri ile belirlenmesi. Eskişehir Osmangazi Üniversitesi İktisadi ve İdari Bilimler Dergisi, 14(3), 899-924.

Yontar, İ. G., \& Aras, B. B. (2018). Motosiklet Kullanımının Kentsel Trafik Güvenliği Üzerine Etkisi: İzmir Üzerine Bir Araştırma. Bitlis Eren Üniversitesi Sosyal Bilimler Enstitüsü Dergisi, 7(2), 611-640.

(C) 2021 by the authors. Submitted for possible open access publication under the terms and (c) (i) conditions of the Creative Commons Attribution (CC BY) license (http://creativecommons.org/licenses/by/4.0/) 